\title{
PREDICTING MOISTURE CONTENT FROM BASIC DENSITY AND DIAMETER DURING AIR DRYING OF EUCALYPTUS AND CORYMBIA LOGS
}

\author{
Antônio José Vinha Zanuncio ${ }^{1, \triangleleft}$, Amélia Guimarães Carvalho ${ }^{1}$, Liniker Fernandes da Silva ${ }^{1}$, \\ José Tarcisio Lima², Paulo Fernando Trugilho ${ }^{2}$, José Reinaldo Moreira da Silva ${ }^{2}$
}

\begin{abstract}
In air drying of Eucalyptus urophylla and Corymbia citriodora logs for the production of charcoal it is necessary to be able to predict when logs have reached the required moisture content of $\leq 35 \%$. This study is aimed to produce models using basic density and diameter to predict the moisture content of Eucalyptus urophylla and Corymbia citriodora logs after 30,60 and 90 days drying. 1,2 m long logs were taken at three different heights from three $C$. citriodora trees and three trees each from two $E$. urophylla clones (VM4 and Mn463). The 27 debarked, end sealed logs were air dried under cover for 90 days during which the change in moisture content was monitored. The relationship between density and drying was analyzed by Pearson's correlation coefficient and the models for predicting the moisture content based on the basic density and diameter were produced. The density and the drying showed a high correlation coefficient. The coefficient of determination of the models was above 0,89 with a standard error lower than $6 \%$. The use of the density and diameter to estimate the wood moisture content simplifies the production of the models, which can be used for Eucalyptus and Corymbia genetic materials.
\end{abstract}

Keywords: Biomass, drying, wood.

\section{INTRODUCTION}

The world seeks to reduce the burning of fossil fuels to reduce the greenhouse effect (Zhu et al. 2011), and biomass use is a viable alternative (Protásio et al. 2013, Musinguzi et al. 2012, Telmo and Lousada 2011).

The charcoal produced from cultivated Eucalyptus spp. is mainly used in the steel production in Brazil. The consumption of eucalyptus logs reached nearly $17 \mathrm{million} / \mathrm{m}^{3}$ in 2011 (Associação Brasileirade Produtores de Florestas Plantadas - ABRAF, 2012), which demands wood with $\leq 35 \%$ moisture content for charcoal production (Brand et al. 2011).

The drying of wood has been studied for over a century (Engelund et al. 2013), but there are few studies on logs. The air-drying method is the most common one to reduce the log moisture content. A reduction of $10 \%$ in the moisture content increases the calorific value by $2 \mathrm{MJ} / \mathrm{kg}$ (Swithenbank et al. 2011). However, in the field, the logs are not dried until the equilibrium moisture content level, because the increase in calorific value is not worth the effort to keep drying after reaching a certain moisture content.

\footnotetext{
${ }^{1}$ Departamento de Engenharia Florestal, Universidade Federal de Viçosa, Viçosa/ MG, Brazil .

2 Departamento de Ciências Florestais, Universidade Federal de Lavras, Lavras/MG, Brazil.

^ Corresponding author: ajvzanuncio@yahoo.com.br

Received: 14.01.2014 Accepted. 17.07.2014
} 
The drying of wood is not homogeneous with higher rates in the early days because of the removal of free water, and this rate decreases until equilibrium moisture content is reached. Environmental factors such as relative humidity, temperature, and wind speed as well as wood factors such as anatomy, density, and diameter of the logs affect the drying process (Larsen and Ormarsson 2013, Mugabi et al. 2010, Rémond et al. 2013, Rezende et al. 2010).

The characteristics such as the diameter and density may allow the use of one type of model to predict moisture content for different genetic material (Zanuncio et al. 2013). The aim of this study was to evaluate the relationship between wood basic density and diameter with drying of wood and establish models for predicting the moisture content of Eucalyptus urophylla and Corymbia citriodora logs after 30,60 , and 90 days of drying.

\section{MATERIAL AND METHODS}

Three $C$. citriodora trees produced from seeds, three from the clone VM4 (E. urophylla) and three from the clone Mn463 (E. urophylla) were used, totaling nine trees. Logs with 1,2 m length were cut and debarked from the base, at $50 \%$, and at $100 \%$ of the commercial height of the trees for the drying process, totaling $27 \log$ cuts (Figure 1).

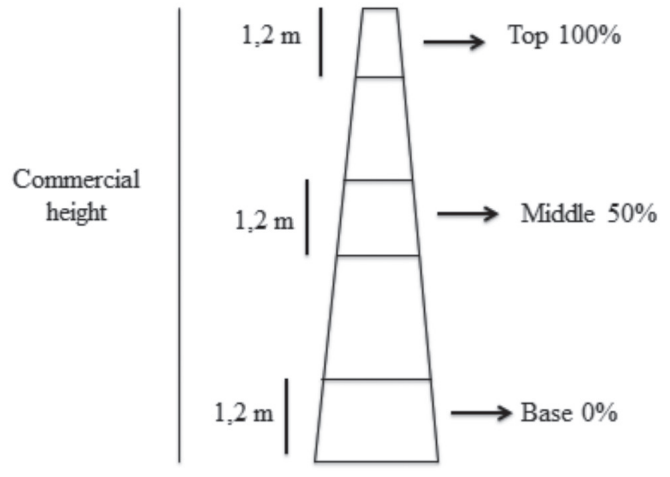

Figure 1. Sampling scheme of logs to evaluate drying.

The C. citriodora and E. urophylla logs had their transverse surfaces waterproofed and placed in a covered area without touching each other. In the first 20 days, the logs were weighed every two days, every four days in the next 30 days and every seven in the next 40 days, totaling 90 days of drying.

A disc of $10 \mathrm{~cm}$ was removed from each pole of the logs after cutting the trees. The moisture content of the disk was determined from the ratio of the water mass and wood dry mass, and basic density was determined from the ratio of the wood dry mass and the wood green volume, according to NBR11941/2003 (Associação Brasileirade Normas Técnicas-ABNT, 2003). The average value of these parameters was considered as the moisture content and basic density of the logs. 
The drying rate was calculated with the formula:

$$
T s=\left(\frac{P U}{D}\right)
$$

where, Ts $=$ drying rate $(\% /$ day $), P U=$ loss of moisture content based on dry mass $(\%)$, and $\mathrm{D}=$ drying period (days).

The relationship between basic density and the initial moisture content, drying rate, and the final moisture content of the logs in their respective diameter classes was obtained with the Pearson's correlation coefficient.

The moisture content of the logs after 30,60, and 90 days of drying was estimated with the model:

$$
U=\exp ^{\left(b_{0}+b_{1} * D e n+b_{2} * D i a\right)}
$$

where $\mathrm{U}=$ Moisture content of the logs after 30,60, and 90 days of drying; Den= basic density of the logs; $D i a=$ diameter of the logs; $b_{0}, b_{1}$, and $b_{2}=$ regression parameters. This model was based on the drying behavior of Eucalyptus logs (Rezende et al. 2010).

The equation was evaluated by coefficient of determination and the standard error of the estimates. Furthermore, a graphic analysis of residues was performed in software SigmaPlot 11.0 to verify the existence of trends.

\section{RESULTS AND DISCUSSION}

The C. citriodora logs showed higher density and lower initial moisture content in the respective diameter classes, with a reverse trend as compared to the Mn463 (E. urophylla) (Table 1). The basic density of E. urophylla clones was similar for the species of this genus, 0,482 to $0,648 \mathrm{~g} / \mathrm{cm}^{3}$, as reported for Eucalyptus benthamii, Eucalyptus camaldulensis; Eucalyptus grandis, Eucalyptus nitens and Eucalyptus urophylla (Couto et al. 2013 Inagaki et al. 2012, Martins et al. 2013, Medhurst et al. 2012).

Table 1. Basic density, diameter and initial moisture content of the Corymbia citriodora and

\begin{tabular}{|c|c|c|c|c|c|}
\hline Material & $\begin{array}{c}\text { Average } \\
\text { height (m) }\end{array}$ & Position & $\begin{array}{c}\text { Basic Density } \\
\left(\mathrm{kg} / \mathrm{m}^{3}\right)\end{array}$ & $\begin{array}{l}\text { Diameter } \\
(\mathrm{cm})\end{array}$ & $\begin{array}{c}\text { Initial moisture } \\
\text { content }(\%)\end{array}$ \\
\hline \multirow{3}{*}{$\begin{array}{l}\text { Corymbia } \\
\text { citriodora }\end{array}$} & \multirow{3}{*}{22,65} & Base & 665 & 17,9 & 78,47 \\
\hline & & Middle & 684 & 12,6 & 75,43 \\
\hline & & Top & 674 & 4,3 & 74,39 \\
\hline $\mathrm{Mn} 463$ & \multirow{3}{*}{30,45} & Base & 508 & 20,3 & 121,52 \\
\hline \multirow{2}{*}{$\begin{array}{c}\text { (Eucalyptus } \\
\text { urophylla) }\end{array}$} & & Middle & 510 & 14,2 & 112,59 \\
\hline & & Top & 511 & 4,6 & 126,15 \\
\hline \multirow{3}{*}{$\begin{array}{c}\text { VM } 4 \\
\text { (Eucalyptus } \\
\text { urophylla) }\end{array}$} & \multirow{3}{*}{29,45} & Base & 529 & 19,4 & 94,54 \\
\hline & & Middle & 579 & 13,3 & 84,52 \\
\hline & & Top & 567 & 4,7 & 80,99 \\
\hline
\end{tabular}
Eucalyptus urophylla logs. 
The genetic materials of $C$. citriodora and the VM4 (E. urophylla) had higher initial moisture content at the base, while those of Mn463 (E. urophylla) were higher at the top. The amount and distribution pattern of moisture content in the longitudinal direction may vary according to the genetic material, as reported for C. citriodora, E. cloeziana, E. grandis, E. paniculata, E. pilularis, E. tereticornis and E. urophylla (Engelund et al. 2013, Oliveira et al. 2005).

The drying rate of all materials was higher in the first 20 days (Figure 2) what was similar to that reported for Cryptomeria japonica lumber and Betula papyrifera flakes (Bedane et al. 2011, Hermawan et al. 2012). This can be explained by the loss of the free water, which is easily removed due to weak capillary connections with the wood (Skaar 1972). However, this rate decreases until the timber reaches the equilibrium moisture content (Rezende et al. 2010).

The logs from the top had the highest drying rates: $0.637 ; 1.224$ and $0.724 \%$ /day for $C$. citriodora, Mn463 (E. urophylla), and VM4 (E. urophylla), respectively, particularly during the first 30 days (Figure $2)$. End sealing normally decreases drying rate because of transverse surfaces lose moisture faster than other surfaces. Logs with smaller diameter had larger surface/volume ratio, resulting in higher drying rate and lower moisture content after 90 days drying. All these logs reached moisture content below $35 \%$, which is recommended for carbonization.

The drying rate of logs from the middle of C. citriodora, Mn463 (E. urophylla), and VM4 (E. urophylla) were $0.611 ; 0.883$ and $0.592 \%$ day, respectively. All these logs reached the final moisture content lower than $35 \%$, as required for carbonization, with shorter period for C. citriodora (Figure 2).

The larger diameter increase the distance traveled by the water inside the wood and reduced its drying rate. The drying rate of C. citriodora, Mn463 (E. urophylla), and VM4 (E. urophylla) was 0.526, 0.669, and $0.601 \%$ /day, respectively (Figure 2). Although with lower drying rate, the lower initial moisture content favored $C$. citriodora logs and only those of the base for this material reached the $35 \%$ moisture content after 90 days of drying, necessary for charcoal production. The reduction in moisture content increases the net calorific value and carbonization yield of the logs (Arruda et al. 2011). 

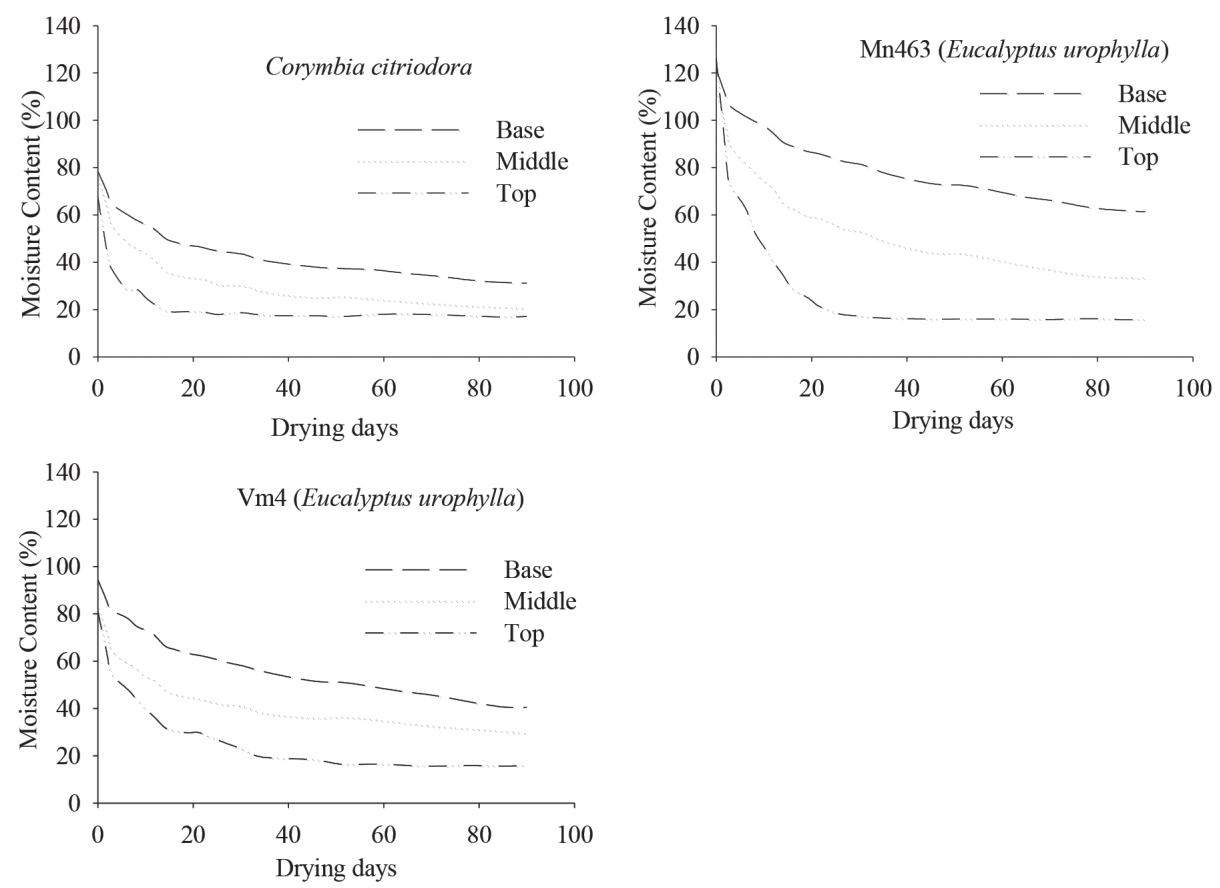

Figure 2. Changes in moisture content of Eucalyptus and Corymbia logs after 90 days of drying.

The density of the timber was inversely proportional to the initial moisture content, drying rate and final moisture content for the base, middle and top materials, except for the relationship between the density and final moisture content of the logs from the top (Table 2).

Table 2. Pearson's correlation coefficient between the basic density of the base, middle and top logs with their initial moisture content, drying rate and final moisture content after 90 days of drying.

\begin{tabular}{cccc}
\hline Position & \multicolumn{3}{c}{ Correlation coefficient } \\
\hline & $\begin{array}{c}\text { Initial moisture } \\
\text { content of logs from } \\
\text { base }\end{array}$ & $\begin{array}{c}\text { Drying rate of logs } \\
\text { from base }\end{array}$ & $\begin{array}{c}\text { Final moisture content of } \\
\text { logs from base }\end{array}$ \\
\cline { 2 - 4 } Basic density from base & $-0,882$ & $-0,861$ & $-0,831$ \\
\hline Basic density from middle & $\begin{array}{c}\text { Initial moisture } \\
\text { content of logs from } \\
\text { middle }\end{array}$ & $\begin{array}{c}\text { Drying rate of logs } \\
\text { from middle }\end{array}$ & $\begin{array}{c}\text { Final moisture content of } \\
\text { logs from middle }\end{array}$ \\
\cline { 2 - 4 } & $\begin{array}{c}-0,886 \\
\text { Initial moisture } \\
\text { content of logs from } \\
\text { top }\end{array}$ & $\begin{array}{c}\text { Drying rate of logs } \\
\text { from top }\end{array}$ & $\begin{array}{c}\text { Final moisture content of } \\
\text { logs from top }\end{array}$ \\
\cline { 2 - 4 } & $-0,869$ & $-0,879$ & 0,255 \\
\hline
\end{tabular}


The basic density showed relationship with the drying, with a correlation coefficient ranging from -0.888 to 0.255 . The wood with lower density has many spaces to be filled by free water, resulting in higher wood moisture content (Skaar 1972). These empty spaces facilitate the flow of water and increase the drying rate, but this was not sufficient to offset the higher initial moisture content of the logs. Therefore, wood with the highest density showed lower moisture content after 90 days of drying, which is similar to that observed for Cryptomeria japonica, Eucalyptus grandis and Tsuga heterophylla lumber (Berberovic and Milota 2011, Mugabi et al. 2010, Watanabe et al. 2012).

Considering the coefficient of correlation between the density and moisture content of the logs from the top. The smaller diameter reduces the distance traveled by the water inside the wood and facilitates the drying of the logs and these reached equilibrium moisture content after 90 days of drying.

Regression models for the moisture content prediction after 30, 60 and 90 days drying showed high correlation coefficient and low standard deviation (Table 3).

Table 3. Regression models for wood moisture content after 30, 60 and 90 days of drying based on basic density and diameter of the Eucalyptus and Corymbia logs.

\begin{tabular}{ccrr}
\hline $\begin{array}{c}\text { Prying Time } \\
\text { (Days) }\end{array}$ & $\begin{array}{c}\text { Estimated model for moisture content after } 30,60 \text { and } 90 \\
\text { days drying }\end{array}$ & $\mathrm{R}^{2}$ & $S_{y, x}$ \\
\hline 30 & $\mathrm{U}=\exp ^{\left(3,97683-2,26202^{*} \mathrm{~d}+0,07328^{*} \mathrm{di}\right)}$ & 0,926 & 5,18 \\
60 & $\mathrm{U}=\exp ^{\left(3,75761-2,21927^{*} \mathrm{~d}+0,07514^{*} \mathrm{di}\right)}$ & 0,921 & 5,14 \\
90 & $\mathrm{U}=\exp ^{\left(3,73064-2,31586^{*} \mathrm{~d}+0,07050^{*} \mathrm{di}\right)}$ & 0,892 & 5,92 \\
\hline
\end{tabular}

$\mathrm{d}=$ basic density $\left(\mathrm{g} / \mathrm{cm}^{3}\right) ; \mathrm{di}=$ diameter $(\mathrm{cm}) ; \mathrm{R}^{2}=$ Coefficient of determination; $S_{y, x}=$ Standard error $(\%)$

The accuracy of the models reflects the high correlation coefficient between the wood basic density and moisture content. The relationship between the moisture content, basic density and diameter showed an exponential curve. Increasing the diameter reduces the surface/volume ratio exponentially, as evidenced by the curve of moisture content for 30,60, and 90 days of drying (Figure 3). Higher density reduces the empty spaces inside the wood and decreases the initial moisture content of the logs, which occurred throughout the drying period for logs with larger diameter. The residue distribution was homogeneous for the three models, showing heteroscedasticity with an upward trend for higher moisture content due to data variability. Other factors inherent of the wood, as the percentage of sapwood also influence the wood drying and may have contributed with the difference between values sampled and the values estimated. 

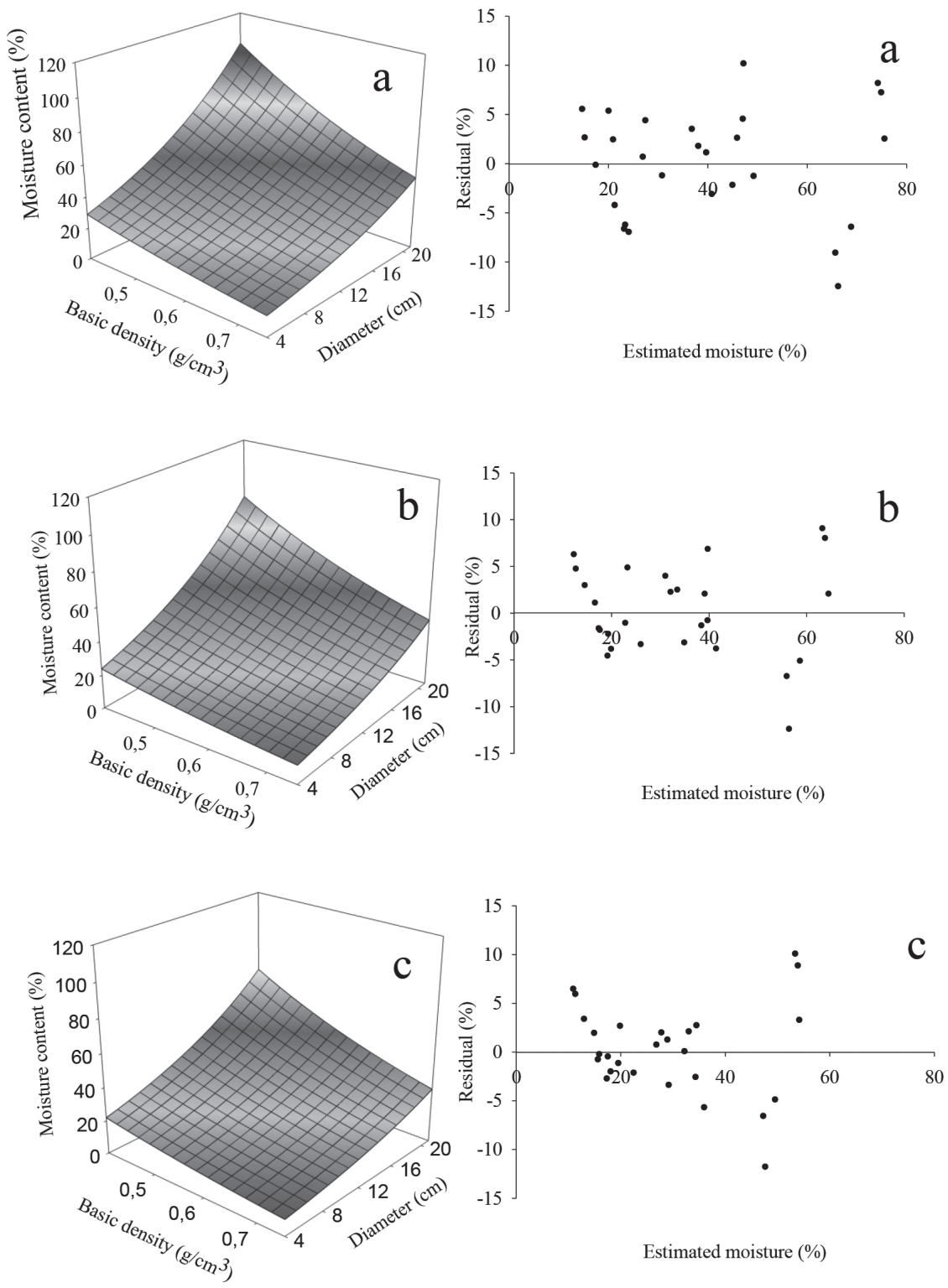

Figure 3. Relationship between moisture content, basic density and diameter with 30 (a), 60 (b) and 90 (c) days of drying.

The moisture content of wood can be predicted from the basic density and diameter of C. citriodora and E. urophylla logs for specific periods. This method can facilitate field operations and reduce costs because the same model can be used for various genetic materials. The models can predict the variability in the moisture content of the wood, but they must be adapted to each climatic condition, because factors such as the temperature and relative humidity also influence the drying (Gebreegziabher et al. 2013, Korkut et al. 2013). Therefore, future studies should also consider the environmental variables to increase the application of these models in the field. 


\section{CONCLUSIONS}

Corymbia citriodora had the lowest moisture content in all periods, while the clone Mn463 (E. urophylla) showed higher values. The high correlation coefficient between density and moisture content allowed the production of models relating to these variables. The models based on the basic density and diameter can be used to estimate the moisture content in C. citriodora and E. urophylla logs after 30, 60 , and 90 days of drying. The wood from genetic materials with higher density showed lower moisture content after the drying period.

\section{ACKNOWLEDGEMENTS}

To "Conselho Nacional de Desenvolvimento Científico e Tecnológico (CNPq)", "Coordenação de Aperfeiçoamento de Pessoal de Nível Superior (CAPES)", V\&M Florestal and "Fundação de Amparo à Pesquisa do Estado de Minas Gerais (FAPEMIG)" for financial support. Global Edico Services edited and proofread this manuscript.

\section{REFERENCES}

Associação Brasileira de Normas Técnicas. ABNT. 2003. Madeira—determinação da densidade básica, NBR 11942. Rio de Janeiro. Brazil

Associação Brasileira de Produtores de Florestas Plantadas. 2012. Anuário estatístico da ABRAF: ano base 2011. Brasília, 145 p.

Arruda, T.P.M.; Pimenta, A.S.; Vital, B.R.; Della Lucia, R.M.; Acosta, F.A. 2011. Avaliação de duas rotinas de carbonização em fornos retangulares. Revista Árvore 35(4): 949-955.

Bedane, A.H.; Muhammad, T.A.; Sokhansanj. S. 2011. Simulation of temperature and moisture changes during storage of woody biomass owing to weather variability. Biomass and Bioenergy 35(7): $3147-3151$.

Berberovic, A.; Milota, M.R. 2011. Impact of wood variability on the drying rate at different moisture content levels. Forest Products Journal 61(6): 435-442.

Brand, M.A.; Muñiz, G.I.B.; Quirino, W.F.; Brito, J.O. 2011. Storage as a tool to improve wood fuel quality. Biomass and Bioenergy 35(7): 2581-2588.

Engelund, E.T.; Thygesen, L.G.; Svensson, S.; Hill, C.A.S. 2013. A critical discussion of the physics of wood-water interactions. Wood Science and Technology 47(1): 141-161.

Couto, A.M.; Trugilho, P.F.; Neves, T.A.; Protásio, T.P.; de Sá, V.A. 2013. Modeling of basic density of wood from Eucalyptus grandis and Eucalyptus urophylla using nondestructive methods. Revista Cerne 19(1): 27-34.

Gebreegziabher, T.; Oyedun, A.O.; Hui, C.W. 2013. Optimum biomass drying for combustion -A modeling approach. Energy 53(1): 67-73.

Hermawan, A.; Fujimoto, N.; Sakagami, H. 2012. Effects of high-temperature and low- humidity pretreatment on the drying properties of sugi boxed-heart timber with black-colored heartwood. Drying Technology 30(7): 780-786. 
Inagaki, T.; Schwanninger, M.; Kato, R.; Kurata, Y.; Thanapase, W.; Puthson, P.; Tsuchikawa, S. 2012. Eucalyptus camaldulensis density and fiber length estimated by near-infrared spectroscopy. Wood Science and Technology 46(3): 143-155.

Korkut, S.; Ünsal, O.; Kocaefe, D.; Aytin, A.; Gökyar, A. 2013. Evaluation of kiln-drying schedules for wild cherry wood (Cerasus avium). Maderas. Ciencia y tecnología 15(3): 281-292.

Larsen, F.; Ormarsson, S. 2013. Numerical and experimental study of moisture-induced stress and strain field developments in timber logs. Wood Science and Technology 47(4): 837-852.

Martins, S.A.; Ganier, T.; Pizzi, A.; Del Menezzi, C.H.S. 2013. Parameter scanning for linear welding of Brazilian Eucalyptus benthamii wood. European Journal of Wood and Wood Products 71(4): 525-527.

Medhurst, J.; Downes, G.; Ottenschlaeger, M.; Harwood, C.; Evans, R.; Beadle, C. 2012. Intra-specific competition and the radial development of wood density, microfibril angle and modulus of elasticity in plantation-grown Eucalyptus nitens. Trees-Struct Funct 26(6): 1771-1780.

Mugabi, P.; Rypstra, T.; Vermaas, H.F.; Nel, D.G. 2010. Relationships between drying defect parameters and some growth characteristics in kiln-dried South African grown Eucalyptus grandis poles. European Journal of Wood Products 68(3): 329-340.

Musinguzi, W.B.; Okure, M.A.E.; Wang, L.; Sebbit, A.; Lovas, T. 2012. Thermal characterization of Uganda's Acacia hockii, Combretum molle, Eucalyptus grandis and Terminalia glaucescens for gasification. Biomass and Bioenergy 46(1): 402-408.

Oliveira, J.T.S.; Hellmeister, J.C.; Tomazello Filho, M. 2005. Variação do teor de umidade e da densidade básica na madeira de sete espécies de eucalipto. Revista Árvore 29(1): 115-127.

Protásio, T.P.; Bufalino, L.; Tonoli, G.H.D.; Guimarães Junior, M.; Trugilho, P.F.; Mendes, L.M. 2013. Brazilian lignocellulosic wastes for bioenergy production: characterization and comparison with fossil fuels. BioResources 8(1): 1166-1185.

Rémond, R.; De La Cruz, M.; Aléon, D.; Perré, P. 2013. Investigation of oscillating climates for wood drying using the flying wood test and loaded beams: need for a new mechano-sorptive model. Maderas. Ciencia y tecnología 15(3): 269-280.

Rezende, R.N.; Lima, J.T.; Silva, J.R.M.; Napoli, A.; Andrade, H.B.; Faria, A.L.R. 2010. Air drying of logs from Eucalyptus urophylla clone for carbonization use. Revista Cerne 16(4): 565-572 .

Skaar, C.J. 1972. Water in wood. Syracuse: Syracuse University, 218p.

Swithenbank, J.; Chen, Q.; Zhang, X.; Sharifi, V.; Pourkashanian, M. 2011. Wood would burn. Biomass and Bioenergy 35(3): 999-1007.

Telmo, C.; Lousada, J. 2011. Heating values of wood pellets from different species. Biomass and Bioenergy 35(7): 2634-2639.

Watanabe, K.; Kobayashi, I.; Kuroda, N. 2012. Investigation of wood properties that influence the final moisture content of air-dried sugi (Cryptomeria japonica) using principal component regression analysis. Journal of Wood Science 58(6): 487-492. 
Zanuncio, A.J.V.; Lima, J.T.; Monteiro, T.C.M.; Carvalho, A.G.; Trugilho, P.F. 2013. Secagem de toras de Eucalyptus e Corymbia para uso energético. Scientia Forestalis 41(99): 353-360.

Zhu, X.; Li, X.; Yao, Q.; Chen, Y. 2011. Challenges and models in supporting logistics system design for dedicated-biomass-based bioenergy industry. Bioresource Technology 102(2):1344-1351. 